\title{
PENINGKATAN PROFESIONALISME GURU SEKOLAH MENENGAH PERTAMA NEGERI (SMPN) DENGAN MELAKUKAN PELATIHAN PENELITIAN TINDAKAN KELAS
}

\author{
Erlinawaty Simanjuntak $^{1^{*},}$, Sudianto Manullang ${ }^{1}$, Marlina Setia Sinaga \\ ${ }^{I}$ Fakultas Matematika Ilmu Pengetahuan Alam, Universitas Negeri Medan, Medan \\ *Penulis Korespodensi: erlinawatys@yahoo.co.id
}

\begin{abstract}
Abstrak
Observasi awal yang dilakukan terhadap 74 guru-guru di SMPN 1 Tanjung Morawa dan SMPN 4 Tanjung Morawa menunjukkan bahwa hanya 10 orang yang mengaku mampu melakukan penelitian tindakan kelas (PTK). Dari 10 guru-guru tersebut hanya 4 orang yang mengaku sudah melakukan penelitian tindakan kelas (PTK) dan 6 guru mengaku tidak termotivasi untuk melakukannya. Sementara 64 guru lainnya memberikan alasan tidak memahami prosedur pelaksanaan, PTK bukan pekerjaan seorang guru. Seyogyanya, pelaksanaan PTK tidaklah hanya sebagai disamping tuntutan administrastif, namun guru harus mampu untuk merefleksi pembelajaran di kelas demi peningkatan kualitas pembelajaran membutuhkan penelitian tindakan kelas. Hal inilah yang menjadi dasar peningkatan profesionalisme guru-guru SMP melalui pelatihan penelitian tindakan kelas di kabupaten Deli Serdang. Pelaksanaan Iptek bagi Masyarakat (IbM) ini adalah untuk membentuk kelompok guru yang mandiri dalam melaksanakan PTK serta mampu menghasilkan laporan serta karya tulis imiah yang dipublikasikan dalam jurnal dengan pendekatan pendampingan yang berkelanjutan. Dosendosen yang sudah berpengalaman dalam hal PTK turut membantu sebagai pembimbing guru-guru tersebut. Pelaksanaan IbM ini memberikan kontribusi peningkatan motivasi guru dalam melaksanakan PTK secara signifikan dimana terdapat 13 orang dari 31 orang guru yang dibimbing dapat menuntaskan kewajibannya sampai pada seminar hasil PTK.
\end{abstract}

Kata Kunci : Jurnal Ilmiah, Penelitian Tindakan Kelas.

\begin{abstract}
Initial observations conducted on 74 teachers at SMPN 1 Tanjung Morawa and SMPN 4 Tanjung Morawa indicated that only 10 of them have the ability to perform classroom action research (PTK). More specifically, 4 out of 10 teachers have engaged with PTK and 6 teachers admitted that they are not motivated to do so. Accordingly, 64 other teachers had lack of understanding in the implementation procedure arguing that, PTK is not a teacher's job. As a matter of fact, the implementation of TOD is not only as a matter of administrative demands, but the teacher must be able to reflect on the classroom learning for the improvement of the quality of learning requires research of class action. This is the basis for improving the professionalism of junior high school teachers through classroom action research training in Deli Serdang district. The implementation of Science and Technology for Society (IbM) is to form a group of independent teachers in implementing PTK and able to produce reports and writings imiah published in the journal with a sustainable approach mentoring. Lecturers who have experience in terms of PTK helped as mentors of these teachers. The implementation of IbM contributed to the improvement of teachers' motivation in implementing PTK significantly where 13 people from 31 guided teachers could complete their obligation until the PTK seminar result.
\end{abstract}

Keywords: Scientific Journal, Classroom Action Research

\section{PENDAhuluan}

Guru sebagai salah satu komponen dalam proses pembelajaran merupakan pemegang peranan yang sangat penting dalam tujuan pendidikan. Guru bukan hanya sekedar penyampai materi saja tetapi lebih dari itu guru dapat dikatakan sebagai desainer pembelajaran. Guru mengarahkan proses pembelajaran agar lebih efektif dan menarik sehingga proses pembelajaran yang disampaikan akan membuat siswa lebih aktif dan tertarik mempelajari materi tersebut, dengan kata lain siswa mempunyai respon positif terhadap materi tersebut.

Pengembangan keprofesionalan guru sangat terkait dengan kegiatan penelitian, khususnya Penelitian Tindakan Kelas (PTK), sebagai bahan 
menyusun Karya Tulis Ilmiah (KTI). Menyusun karya ilmiah merupakan salah satu indikasi bahwa guru dapat dikatakan profesional. Selain itu bagi guru berstatus PNS untuk dapat menduduki golongan IVb harus memiliki karya ilmiah. Salah satu indikator dari pencapaian kompetensi guru adalah melakukan penelitian tindakan kelas, yang berujung pada pelaporan yang merupakan salah satu bentuk karya ilmiah. Dengan demikian dapat disimpulkan bahwa guru yang profesional salah satunya adalah melakukan kegiatan penulisan karya ilmiah, baik dalam bentuk kajian teori maupun hasil penelitian.

PTK pada hakekatnya merupakan kegiatan ilmiah yang dapat digunakan sebagai bahan refleksi untuk kegiatan pembelajaran di kelas secara ilmiah dan dapat dipertanggung jawabkan. Karena PTK merupakan penelitian yang dilakukan oleh guru dikelasnya sendiri berdasarkan permasalahan yang dialaminya. Menurut Rochiati (2005: 21) bahwa: "Penelitian tindakan kelas bukan bertujuan untuk menghasilkan pengetahuan atau teori, melainkan menghasilkan produk berupa peningkatan kemampuan intelektual siswa". Hal ini senada dengan pendapat Sarwiji Suwandi (2007: 13) yang mengatakan bahwa "PTK bertujuan meningkatkan kinerja guru dan hasil belajar siswa, bukan saja mengungkapkan penyebab berbagai permasalahan yang dihadapi dalam pembelajaran".

Guru-guru di SMPN 1 Tanjung Morawa dan SMPN 4 Tanjung Morawa beserta rayon belum termotivasi untuk memperbaiki proses pembelajaran dikelas. Hal ini disebabkan karena kemampuan yang rendah akan penguasaan model maupun metode pembelajaran yang berakibat pada pembelajaran yang monoton. Selain guru-guru juga kurang menguasai prosedur penelitian khususnya penelitian tindakan kelas yang bermuara pada kemampuan menulis karya tulis ilmiah. Organisasi pengembangan profesi guru melalui Musyawarah Guru Mata pelajaran (MGMP) sejatinya sudah melakukan peranan dalam meningkatkan pengetahuan guru terhadap model, metode maupun teknik pembelajaran. Forum ini dapat diberdayakan sebagai wadah bagi guru untuk dapat melakukan PTK secara berkoloborasi. Pengetahuan guru dalam melakukan PTK yang rendah merupakan salah satu permasalahan yang harus disikapi.

Untuk itu kegiatan pengabdian masyakat ini bermaksud untuk membekali guru akan kemampuan melaksanakan PTK yang berkesinambungan. Ini merupakan upaya dan langkah nyata dalam bentuk pembimbingan sebagai wujud kegiatan pengabdian, sehingga guru mampu berkarya dan berprestasi dalam berbagai kegiatan ilmiah dan didukung oleh berbagai pihak.

\section{TARGET}

Pelatihan PTK bagi guru-guru di SMPN 1 Tanjung Morawa dan SMPN 4 Tanjung Morawa beserta sekolah rayonnya menjadi target dalam kegiatan pengabdian ini yang berjumlah 30 orang guru. Khususnya guru-guru yang membutuhkan adanya karya ilmiah sebagai persyaratan kenaikan pangkat dan jabatan fungsionalnya. Bagi sebagian besar guru, menulis proposal PTK merupakan hal yang sangat sulitt untuk dilakukan. Kategori berat yang mereka rasakan pada dasarnya karena kekurangpahaman mereka tentang bagaimana cara menuis proposal PTK yang sistematis. Oleh karena itu, selama pelatihan ini berlangsung diharapkan guru-guru mampu: (1) Memaparkan materi tentang gambaran umum PTK yang meliputi definisi PTK, manfaat PTK, komponen-komponen dalam PTK, langkah-langkah melaksanakan PTK, (2) Mengenal proposal PTK yang meliputi format proposal PTK, sistematika Proposal PTK, dan yang terpenting isi dari proposal PTK, (3) Menyusun proposal PTK oleh guru secara individu dengan didampingi oleh pembimbing (4) Menyusun hasil PTK dalam bentuk laporan penelitian dan artikel ilmiah yang akan diterbitkan dalam jurnal.

\section{METODE PELAKSANAAN}

Bentuk penyuluhan dan pelatihan penyusunan proposal penelitian tindakan kelas dalam kegiatan pengabdian kepada masyrakat ini dibagi menjadi beberapa tahap yaitu: (1) ceramah/penyuluhan dan bimbingan, metode ini digunakan untuk menjelaskan tentang cara-cara dan langkah-langkah penyusunan proposal penelitian tindakan kelas disertai dengan berbagai macam contoh proposal, (2) pemberian pelatihan secara klasikal, melalui metode ini peserta pengabdian berlatih menyusun proposal penelitian dengan bimbingan tim pengabdian, (3) pemberian pelatihan secara mandiri, para peserta pengabdian berlatih secara individu menyusun proposal penelitian tindakan kelas, (4) presentasi secara individu, para peserta secara individu mempresentasikan proposal penelitian yang telah disusun, (5) perbaikan proposal, berdasarkan masukan dari peserta pelatihan yang lain dan tim pengabdian. Peserta pengabdian memperbaiki poroposal yang telah dipresentasikan. Dengan kegiatan-kegiatan tersebut diharapkan pemahaman dan keterampilan guru-guru SMP dalam menyusun proposal penelitian tindakan kelas lebih meningkat.

Setelah proposal selesai maka guru-guru tersebut langsung menjalankan penelitiannya di kelas masing-masing sampai tercapai hasil dan pengumpulan data yang dibutuhkan untuk dilanjutkan pada penyusunan laporan penelitian tindakan kelas. Pada tahap ini guru-guru masih terus dibimbing sampai pada seminar hasil PTK dan pembuatan artikel ilmiah untuk diterbitkan pada jurnal.

\section{HASIL}

Adapun hasil yang dicapai pada kegiatan Pelatihan Penelitian Tindakan Kelas (PTK) dan Penulisan Karya Ilmiah (PKI) untuk Meningkatan Profesionalisme Guru-Guru SMP di Kabupaten Deliserdang adalah sebagai berikut:

\subsection{Inventarisasi Kebutuhan Pihak Sekolah}


Pada tahap ini hasil yang diperoleh adalah kesediaan mitra kerja (pihak sekolah ) untuk mengikuti Pelatihan Penelitian Tindakan Kelas (PTK) dan Penulisan Karya Ilmiah (PKI) untuk meningkatan Profesionalisme Guru-Guru SMP di Kabupaten Deliserdang. Pada proposal hanya terdapat 2 sekolah sebagai mitra kerja, namun karena antusias yang tinggi dari sekolah lain, maka mitra bertambah dari 3 sekolah lain, sehingga ada 5 sekolah yang turut serta dalam kegiatan pelatihan ini. Adapun mitra kerja yang turut serta dalam pelatihan ini adalah SMPN 1, SMPN 2, SMPN 3, SMPN4 dan SMPN 5 di Kecamatan Tanjung Morawa Kabupaten Deliserdang dengan jumlah peserta seluruhnya sebanyak 31 orang guru dari berbagai bidang studi.

\subsection{Peningkatan Hubungan Tim Dengan Pihak Sekolah}

Dalam kegiatan pelatihan ini, keberlangsungan kerja sama tetap terjalin baik. Komunikasi tim pengabdian dengan setiap kepala sekolah dan juga guru-guru berjalan dengan baik dan penuh keakraban selama pelatihan dan pendampingan PTK dan PKI yang berkelanjutan dalam kurun waktu 6 bulan. Masing-masing mitra kerja mengirimkan guru-guru yang membutuhkan pelatihan PTK dan PKI untuk memenuhi kebutuhan kenaikan pangkat dan fungsional.

\subsection{Pencapaian indikator}

Sesuai dengan target dari kegiatan ini yaitu dimulai dari pemaparan tentang PTK, pelatihan penulisan proposal PTK dilanjut dengan pelaksanaan di kelas masing-masing guru sampai akhirnya diperoleh data. Setelah itu guru-guru melakukan pengolahan data dan menyusun laporan akhir dari PTK mereka secara lengkap. Berdasarkan laporan akhir guru-guru tersebut, mereka dibimbing kembali untuk membuat artikel sebagai karya ilmiahnya untuk diterbitkan dalam jurnal.

Selama pembimbingan ini berlangsung, ada banyak hal yang dihadapi oleh tim pengabdian. Diantaranya (1) kegiatan guru-guru yang juga padat di sekolah sehingga terbentur dengan waktu pembimbingan yang kadang kala harus diundurkan; (2) motivasi guru-guru yang menurun ketika mereka merasa kurang mampu melanjutkan penelitiannya; (3) minimnya pengetahuan guru terhadap modelmodel pembelajaran; (4) penguasaan ICT yang masih rendah. Namun dengan kerjasama dan komunikasi yang baik antara tim pengabdian dengan masingmasing peserta, masalah diatas dapat diatasi walaupun tak semuanya berhasil. Dari 31 orang peserta yang mangikuti pembimbingan ini, ada sebanyak 13 orang peserta yang berhasil sampai pada menyeminarkan hasil PTK nya. Dan ini sudah melebihi dari target yang ditetapkan oleh tim pengabdian.

Dilihat dari hasil Seminar PTK, guru-guru tersebut sudah mampu dan percaya diri untuk berdiri menyajikan hasil penelitiannya didepan teman-teman sejawat dan para pemberi saran. Tampilan slide powerpoint yang mereka sajikan juga sudah bervariasi dengan memakai berbagai animasi. Dan pengakuan mereka, cukup bangga berhasil sampai pada tahap ini.

\section{KESIMPULAN DAN SARAN 5.1 Kesimpulan}

Dari kegiatan yang sudah dilaksanakan, banyak hal yang dialami sebagai pengalaman berharga bagi kami dosen muda sebagai pelaksana. Ada beberapa hal yang dapat dijadikan kesimpulan sekaligus temuan dari kegiatan ini, diantaranya yaitu:

1. Melalui kegiatan ini banyak guru yang sebelumnya belum mengerti menjadi mengerti apa itu PTK/PKI dan bagaimana cara membuat serta mempraktekkannya di kelas masing-masing

2. Meningkatnya motivasi menulis guru-guru, hal ini mungkin disebabkan pengetahuan mereka yang sudah bertambah tentang cara menulis karya ilmiah.

3. Guru-guru lebih banyak mengenal model-model pembelajaran yang berkembang sebagai alat bantu menyelesaikan masalah pembelajaran di kelas.

4. Laporan akhir dari PTK guru-guru tersebut sudah memenuhi standar laporan yang diminta dan layak untuk diterbitkan

\subsection{Saran}

Adapun hal-hal yang disarankan dari hasil kegiatan ini adalah:

1. Perlu dilakukan kegiatan bagi guru-guru yang berhubungan dengan kebutuhan mereka dalam melaksanakan pembelajaran di kelas, seperti: model pembelajaran, pelatihan PTK dan pelatihan ICT.

2. Kegiatan seperti ini juga perlu dilakukan di daerah-daerah lain karena masih banyak guruguru yang belum mampu membuat PTK sehingga mereka tidak bisa untuk naik pangkat.

\section{DAFTAR PUSTAKA}

Andreas, Priyono. 2001. PetunjukPraktis Classroom Base Action Researh.Semarang: Kanwil Depdiknas ,Propinsi Jawa Tengah.

Anonim. 1999. Penelitian Tindakan Kelas. Jakarta: Dirjen Dikti.

Rochiati, W. 2005. Metode Penelitian Tindakan Kelas. Bandung: Rosdakarya.

Sarwiji Suwandi. 2007. Penelitian Tindakan Kelas. Surakarta: Panitia Sertifikasi Guru.

Sudjana, Nana. 2003. Penelitian dan Penilaian Pendidikan. Bandung: Sinar BaruOffset.

Suhardjono, Azis Hoesein, dkk. 1996. Pedoman Penyusunan Karya Tulis Ilmiah di Bidang Pendidikan dan Angka 
KreditPengembangan Profesi Guru. Jakarta: Depdikbud, Dikdas.

Suharsimi, dkk. 2008. Penelitian Tindakan Kelas. Jakarta. Bumi Aksara.

Sukidin, .2004. Management Penelitian Tindakan Kelas. Jakarta. Intan Cendikia.

Wibowo, M.E. 2007. Panduan Penulisan Karya Ilmiah. Semarang: UnnesPress.

Zainal Aqib, 2006. Penelitian Tindakan Kelas Untuk Guru. Bandung: Yrama Widya. 